\title{
Correlation Between Quality Of Environment And Quality Of Life, In Trimulyo Village, Genuk Sub-District, Semarang Indonesia
}

\author{
Parfi Khadiyanto ${ }^{1}$, Soetomo, $\mathrm{S}^{2}$ Hadi, $\mathrm{SP}^{2}$ \\ $\left.{ }^{1}\right)$ Urban and Regional Planning Department, $\left.{ }^{2}\right)$ Doctorate Programme of Architecture and Urbanism, \\ Faculty of Engineering, Diponegoro University, Semarang, Indonesia
}

\begin{abstract}
About 20 years ago, in the Trimulyo village, Genuk Sub-districts, the community still feels comfortable to live in, a river that flows in the region can still be used for washing, and as a playground for children (pool and bath), the well is still clean. But after Genuk Sub-districts started many emerging industrial area, then begin a wide range of environmental issues toward this region. Currently in the Trimulyo village Genuk Sub-districts, shallow wells can not be utilized as a source of clean water, as well as river conditions ranging turbid, have a dark color of water, foul odor, especially when the dry season arrives.

Settlements in Trimulyo village is one of the victims of the land use change from fishery and agricultural (rural) to industrial (urban). Many farmers and fishermen, who then turned as a laborers, or they have to moved after the land was purchased for the construction industry. For those who stayed, their work changed as industrial workers, or open food stalls, or rent out his house to the settlers.

Environmental quality are positively correlated with the quality of human life, if the quality of the environment ugly then so did the quality of its human (Sarwono, 1992).

This study examines the correlation between environmental quality and the quality of human in the settlements of neighborhoods in Trimulyo village. The quality of the environment detected by the condition of the buildings, facilities and infrastructure, location and accessibility, as well as the comfort of the physical environment. While quality of life is detected through health, economic, educational, and social relationships.

The results showed that not all regions with poor environmental physical conditions certainly people have a poor quality of life as well, because it turns out that the poor environmental can still grow social kinship attitudes that is able to raise the degree quality of life. In addition, the quality of public education is relatively good, will improve the quality of life as well. So in this Trimulyo village, although the quality of the environment is ugly, but the quality of life is in good category.
\end{abstract}

keywords:- quality of life, environmental quality, settlements, Semarang, Indonesia

\section{BACKGROUND}

Semarang is now facing land subsidence of which speed reaches $8 \mathrm{~cm}$ per year. The land is directly adjacent to the sea so that this location suffers real loss of the sea water rise and relative sea water rise. In fact, this location has great number of population and is the center of industrial activity in Semarang. The location suffers from this environmental degradation is located on the East-west of the city that is Genuk Sub-district.

GenukSub-district is a suitable area for urban activities which include industrial activities, settlements, and other life activities. The land is flat (the slope is only 5\%) and has traffic lanes connecting big cities in Java (Jakarta-Surabaya). Unfortunately, there is a great land subsidence that is $8 \mathrm{~cm}$ per year (Khadiyanto, 2005). Thus, Genuk area is unquestionably flooded by the tide. In this poor condition, however, the people still put their interest to settle in this area which is proven by the every-year population growth in this sub-district. In Semarang, PedurunganSub-district faces the highest population growth, seen from the coming inhabitants, then Ngalian, West Semarang, Tembalang, Banyumanik, and GenukSub-district. It shows that even though GenukSub-district suffers from environmental degradation due to the land subsidence and is always inundated due to the sea level rise which is occurred twice in a month. Yet it does not lessen the people' interest to come to GenukSub-district. 


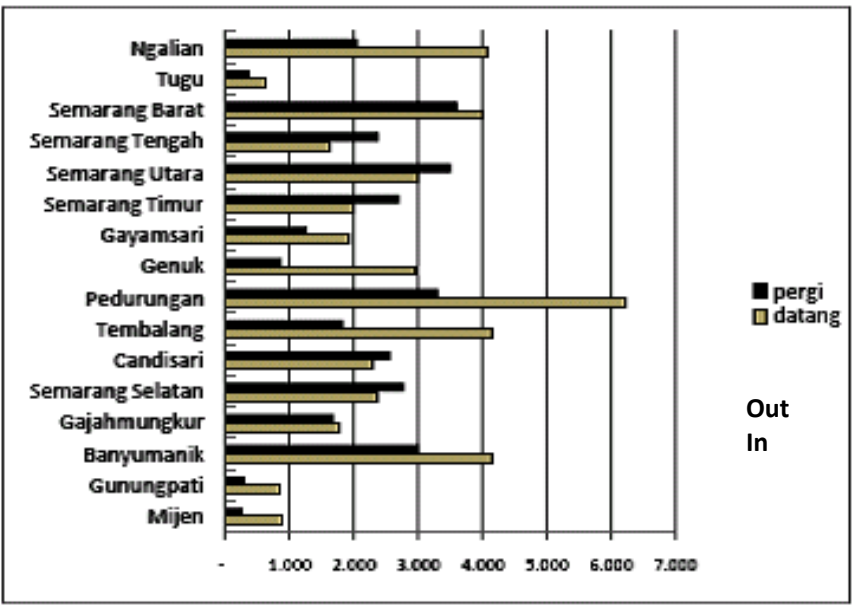

Figure 1: Graph the proportion of people who go and come in Semarang per subdistrict, 2010 (Source: Planning And Regional Development AgenciesSemarang City, 2010)

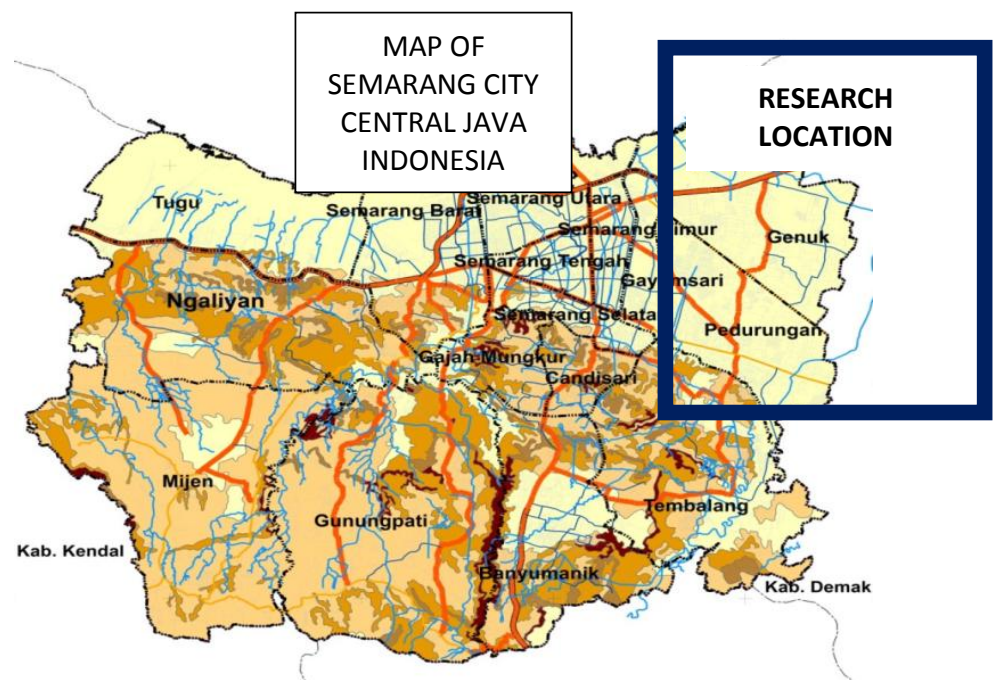

Figure 2:Map of research locations in the Trimulyo village, Genuk sub-district, Semarang City (Map source: Planning And Regional Development AgenciesSemarang City, 2010)

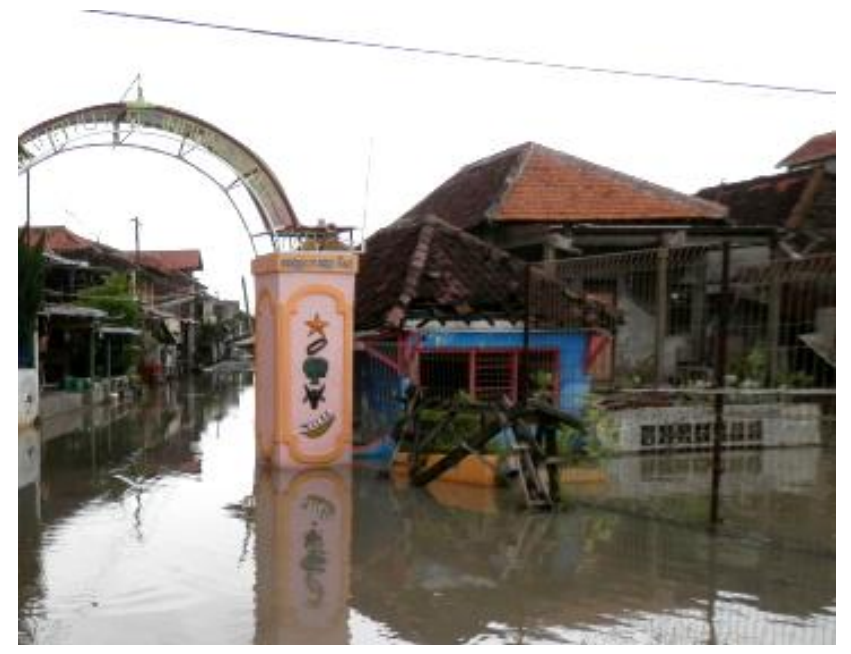

Figure 3:Condition of the settlements which are always flooded 


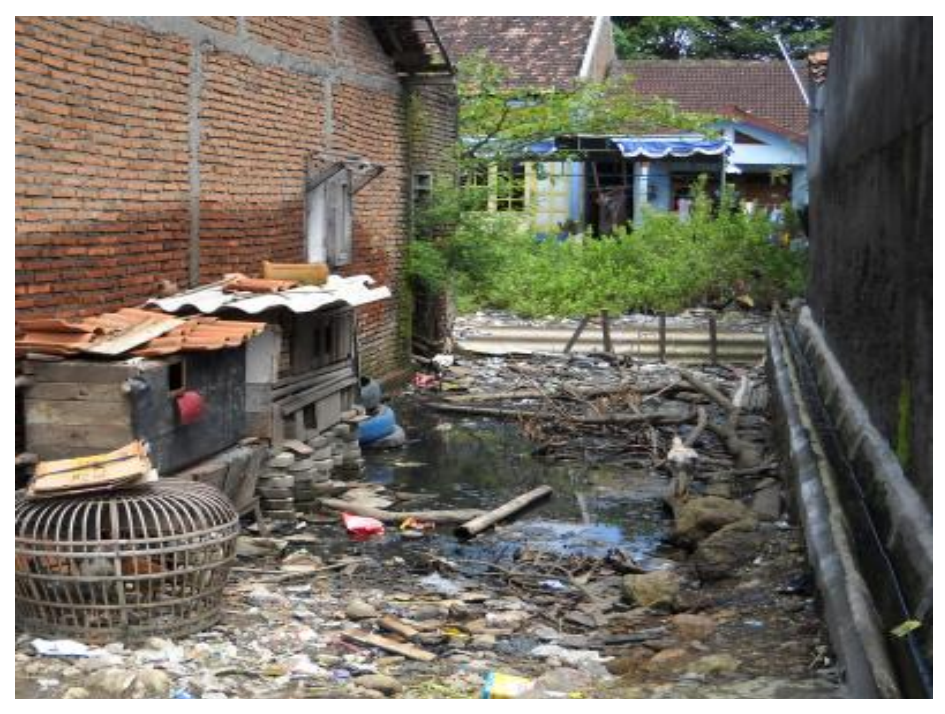

Figure 4: When the flood was gone, the ground becomes muddy and dirty

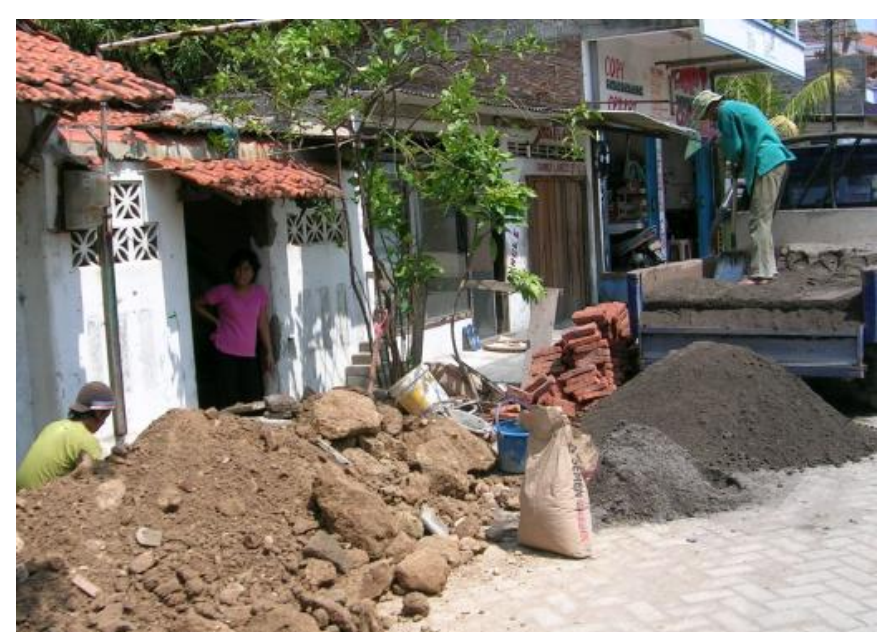

Figure 5:Almost every year, they have to repair the house, build a higher, or make a dike in front of the house

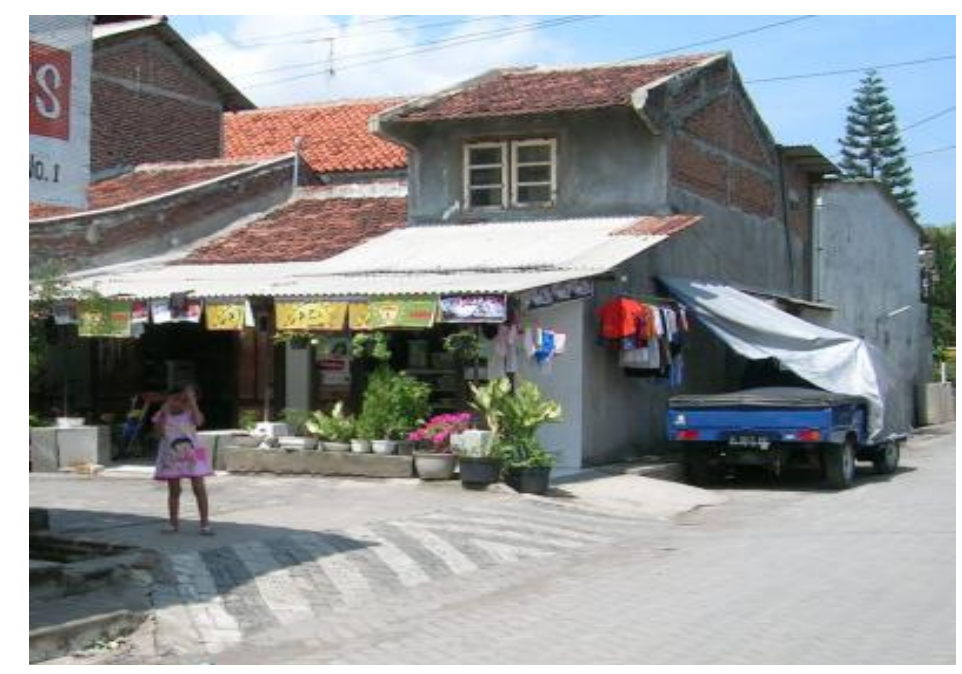

Figure 6:The rich group, they set the environment becomes clean and comfortable 


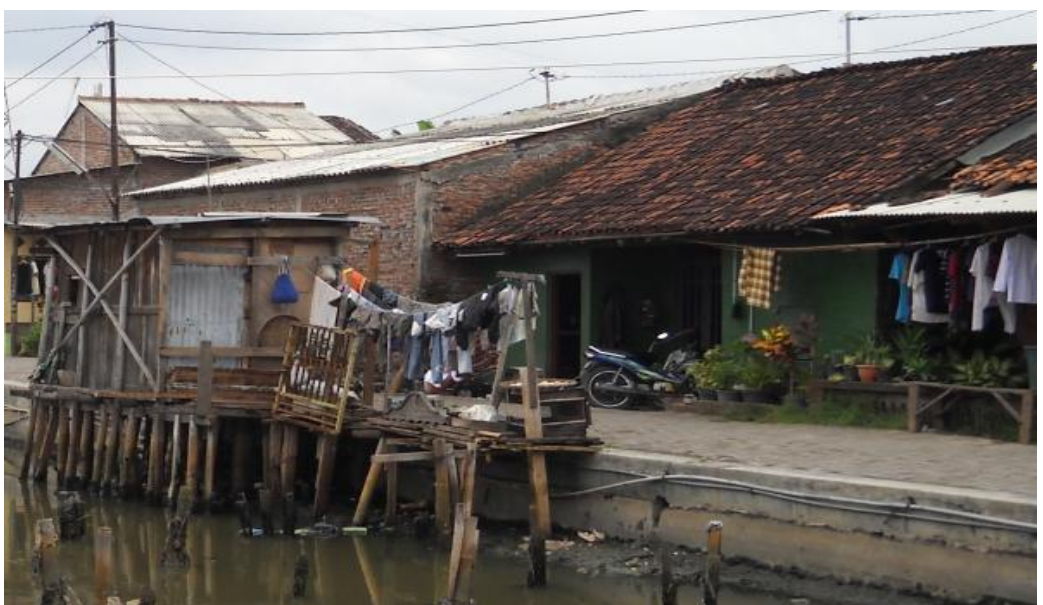

Figure 7:There are still some people who do not have personal sanitation, they use the river as a bathroom and

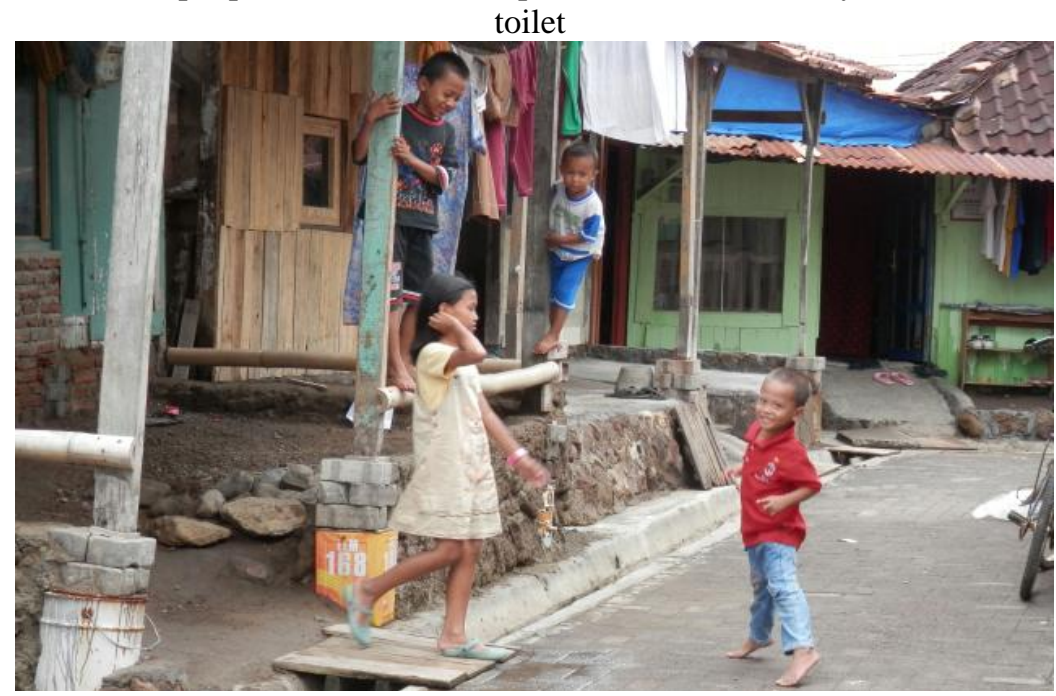

Figure 8: The playground for Children is on public roads

A human is a creature having great adaptation capability. Almost all kinds of habitat are occupied by human such as coastal area to the high Andes, from tropical forest to hot, dry, and humid dessert and to arctic area full with ice. With their great capability to adapt, human population keeps growing and is ready to occupy any new habitats. There are three process of adaptation (Sarwono, 1992) that are (1) Physiologic adaptation - a physiologic change within the actor of adaptation, (2) Morphologic adaptation - shape adjustment on the actor of adaptation, and (3) Cultural adaptation - that is life style adjustment done by the actor of adaptation.

Soemarwoto (1991), explains that the quality of the environment can't be easily determined, it is because people's perceptions of the environment quality is different. With a simple formula mentioned that someone will declare the environmental quality was good when the environment can make people feel comfortable, feel at home, comfortable for a long stay. The comfortable feeling caused by several factors, such as the considerable economic, climatic conditions of an environment, and other natural factors that according to human feelings. Feeling comfortable is subjective. Enjoy staying or pleasure to stay, is not the same as filling happy, enjoy staying showed that he wanted to stay longer in there. There are certain factors that affect optimum for comfortable and "enjoy to stay", like feel at home is. In general, the quality of the environment can be considered as something that meets the preferences of imagination ideal person or group of people (Bronfenbrenner, 1979). Environmental quality is a subjective assessment associated with the psychological aspects and socio-cultural communities that inhabit in a housing area. While quality of life is a multidimensional and complex, have many linkages between economic, social, cultural, and psychologi (Halim D. 2005). The need of essential life, referred to as the basic living needs. People's perception of basic needs will vary, because it is also influenced by social, cultural, economic, psychologi, and also time, as well as consideration of the needs of short-term and long-term. Quality of life is basically dependent on the fulfillment of basic needs of each individual(Klien D.C. 2005;Samsunuwiyati P. 2006). The better the basic needs are then met the better 
quality of life. Quality of life was often irreparably if not essential life needs can also be met. However, if basic needs can not be met, the fulfillment of which are not essential does not make much sense (Soemarwoto 1991), according that, the quality of human life turns out is determined by three (3) things:

1. Meeting needs of life as a living being, or referred to as a basic necessity.

2. Meeting needs as a human life, or so-called civilized beings.

3. To fulfill the need for the ability to choose, or referred to as an alternative property that much.

From the description above, it can be concluded that the quality of life seen from the aspect of health, economy, education, and social relationships. Environmental quality housing can be measured based on the physical aspects of the condition of settlement, type of dwelling, home ownership, environment and the availability of facilities (Kuswartojo, Tjuk, et al., 2005). Budihardjo (1996) and Catanese (1986) mentions factors that can be used to assess the quality of the residential environment is as follows:

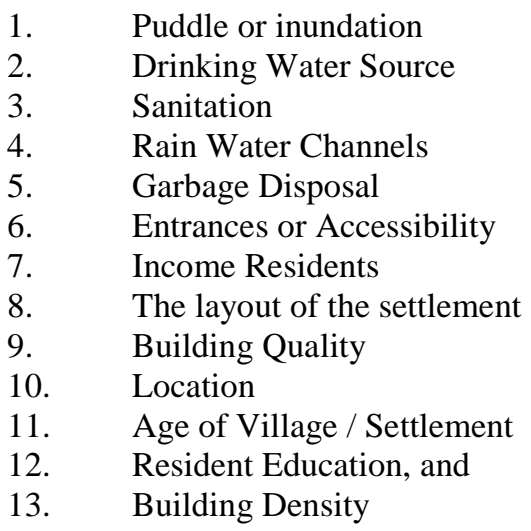

Environmental quality is a measure of the quality of the environment in which people can feel comfortable in that place. The quality of this environment can be measured both subjectively and objectively. Subjectively can be seen from the base desires of each individual, and objectively viewed by the physical condition of the environment, whether natural or artificial (Turner, John F.C, 1976). In addition there is a certain threshold of basic needs according to Maslow (1943) which can be connected with the meaning of a house, that they got some sense according to their respective needs, among others:

1. Physiological Needs, houses provide protection against natural disturbances and animals, as a private family, and serves as a resting place.

2. The need for a sense of security, as the place to conduct rituals, a place to store belongings, guaranteeing personal rights.

3. The need for social relations, the home provides an opportunity for interaction and communication activity that is familiar with the surrounding neighbors. Humans require recognition of ownership, and this means that human beings need social contact in the environment. The house needs a residential neighborhood as a unit that can be identified by their environmental activities, the layout of the house, shape of the house, spatial patterns, as well as other environmental completeness.

4. The need for self-esteem, the house and dwellings are the measures of success.

5. The need for self-actualization, the house is regarded as a personal development for the residents, the house is a symbol of social status.

Then the quality of the environment assessed on the aspects of the physical condition of residential buildings (houses), the completeness of infrastructure neighborhoods, distance to public facilities, accessibility and comfort of the environment as a place for living, comfort are highly individual, so the measure is on the perception of the residents themselves (Hutchison R, 2010; Halim D, 2005; Marsella J, 2004).

\section{RESEARCH OBJECTIVES}

This study aims to assess the correlation between the quality of the environment in Trimulyo with a quality of life which occupied the site. The quality of the environment detected by the condition of the buildings, facilities and infrastructure, location and accessibility, as well as the comfort of the physical environment. While quality of life is detected through health, economic, educational, and social relationships that occur in the site.

\section{METHODOLOGY}

The method used in this research is using quantitative approach, through descriptive analysis. Data analysis by describing the findings in the field that have been quantified, to answer the kinds of research 
questions. Variables used in the quantitative analysis requires assumptions about the meaning of social life, especially about how it is understood by the respondents (Nawawi H, 1987). Quantitative research with descriptive format aims to explain, and summarize various situations, or the many variables that arise in the community as the research object, based on what is happening.

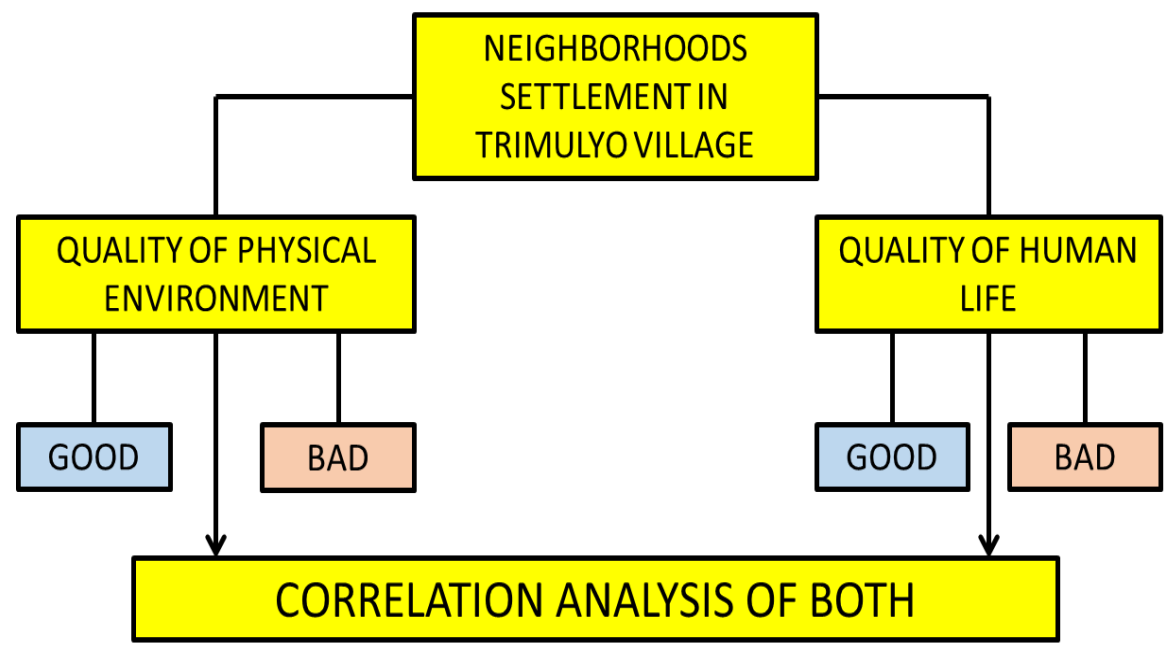

Figure 9:Diagram framework to find a correlation between the quality of the environment and quality of life

bel 1: DATA USED IN THE ANALYSIS PROCESS

\begin{tabular}{|c|c|c|}
\hline Variable & Parameter & a way to assess \\
\hline \multirow{5}{*}{$\begin{array}{c}\text { ENVIRONMENTAL } \\
\text { QUALITY }\end{array}$} & $\begin{array}{l}\text { Building Physical } \\
\text { Condition }\end{array}$ & \multirow{5}{*}{$\begin{array}{l}\text { using ratings from } \\
\text { Likert scale, from } \\
\text { grades } 1 \text { to } 4 \text { points }\end{array}$} \\
\hline & $\begin{array}{l}\text { Completeness of facilities } \\
\text { and infrastructure }\end{array}$ & \\
\hline & Distance to public facilities & \\
\hline & Accessibility & \\
\hline & $\begin{array}{l}\text { For the comfort of living } \\
\text { (public perception) }\end{array}$ & \\
\hline \multirow{4}{*}{ QUALITY OF LIFE } & Health & \multirow{4}{*}{$\begin{array}{l}\text { using ratings from } \\
\text { Likert scale, from } \\
\text { grades } 1 \text { to } 4 \text { points }\end{array}$} \\
\hline & Economy & \\
\hline & Education & \\
\hline & Social Relationship & \\
\hline
\end{tabular}

Information: $\mathbf{1}$ = not good; $\mathbf{2}$ = poorly; $\mathbf{3}$ = good; $\mathbf{4}$ = very good (Source: Nawawi H, 1987; Maimunah S. et.al, 2011; Budihardjo, 1998)

\section{RESULTS AND DISCUSSION}

\section{The Three Community Groups}

With a population of 8,766 people, randomly sample selected of 100 samples, each unit of the house only have one sample only, so that 100 samples representing 1,768 the house (households). Results of the study are as follows:There are three classes of economy class in the area of research, namely the low-income group and without special skills, intermediate group with one or two skills, and a the capable group of fixed income and well educated.First, most low-income groups, those working in the informal sector, their number as much as $28 \%$, come to the location due solely to find a job, with no special skills, so get into the informal economy. Living in Trimulyo better than living in their villages before, the average income below Rp 2.000.000, - per month is pretty good compared to previous without income while still in the village. This group is poorly educated (mostly just graduated from elementary school and have not graduated from junior high school).

Second, the next group, namely that earn between Rp 2.000.000, - up to Rp 4.000.000, -. The majority worked in a factory as a laborer, the average of their education at the secondary level to intermediate (SMA / SMK sd D3), as much as 47\%. On average have one or two job skills, and have a clear working hours. 
Third, the last group, is a group of rich people, earning $\mathrm{Rp} 4.000 .000$, - more, there is as much as $25 \%$, the level of education they mostly own scholars (graduate Universities), the type of work is as Civil servant/ Military-Police/ Landlord/ Trader/Businessman, and they have diverse skills.

Of these three groups, it turns out have different views about the meaning of living and life around the industrial area in Genuk. For the poor (informal sector), stated that the conditions in Genuk much better than the conditions in his native village, what they mean is better in terms of earning. Regarding the environmental conditions of flooding, there is no problem, which is important to money for food and daily living.

The middle class (high school and D3) states that, Genuk is a temporary place, because they feel that the money generated could be used to survive, and there is still a bit for savings, also for school fees of children, thus staying in Genuk temporarily retained. Flooding has been very disturbing, which is why they claim that Genuk only temporarily, if there are other places better than Genuk (which always floods) but can provide income like in Genuk, they would move. The majority of those states do not have other alternatives to move, because the other industrial sites in Semarang not as good as in Genuk.

And the top group (group of rich people) are Civil servants/ Military-Police/ Merchant/ Trader, and Landlord, says that wants to to stay in Genuk because maintaining the assets that they already have here, landlords have houses and land for rent, houses for rent to workers, and land leased to trader stalls and workshops. Most of these groups are have 2-storey house. If there is a neighbor who moved because it no longer felt comfortable with the environment, the houses was bought to expand his land, or to be rebuilt to be used as a rental house, so that the majority of the civil servants/ military/ merchant/ businessman has more than one house, so easier to save anything when the flood came. This group assessment of the condition of the environment is still comfortable to be a place to stay, although it is always flooded, dusty and dirty. The more neighbors moved more pleased for them, because the more land to be able to him to have, the price of land in this place is very cheap for them, price at that time (2013) around Rp 250,000 per square meter. Rarely people who live outside of the region do not want to buy, because it is in the flooded area.

Humans are creatures who have two ways in order to survive, there are two options that actually contradictory (Marsella, 2004), namely the one hand to lead the growth, and the other is to look for security (defense). What security means is passive, tend to avoid or survive, while the growth is towards more active movements, namely to control what is in the range of abilities. To do with the choice of location to settle in areas that are already degraded, it turns out economic factors become key drivers of active attitude or aggressive, while the safety and security of the resident is not a priority, they stated that they could adapt to the environmental conditions that are less good, the attitude of this adaptive more to the behavior of defensive and not aggressive.

\section{Correlation between Environmental Quality with Quality of Life}

After getting the characteristics of society in terms of income, then do an assessment of the physical condition of the settlements. The condition is correlated with respondents of the questionnaire that leads to their quality of life assessment. The answer from respondents is a selection of answers to a series of closed questions that already have a certain score. From individual score, combined into a total score which is then to be averaged. Maximum score obtained at 4 , and the minimum score is 0 (zero), so that when the average answer of the score is risen above 2 (two), the quality is likely to lead to good, but if there is less than 2 (two), it will fall into the category of less good (bad).Findings in the field, after each respondents combined and counted, then obtained the following results:

\begin{tabular}{lc}
$\begin{array}{l}\text { Tabel 2: VALUES OF ENVIRONMENTAL QUALITY AND QUALITY OF LIFE } \\
\text { Parameter }\end{array}$ & \\
\hline \multicolumn{2}{c}{ Score } \\
\hline ENVIRONMENTAL PHYSICAL CONDITION: & 0.97 \\
\hline Building Physical Condition & 1.67 \\
Completeness of facilities and infrastructure & 1.72 \\
Distance to public facilities & 1.88 \\
Accessibility & 2.76 \\
For the comfort of living (public perception) & $\mathbf{1 . 8 0}$ \\
\hline Average & \\
\hline
\end{tabular}

\begin{tabular}{lc} 
QUALITY OF LIFE: & \\
\hline Health & 0.97 \\
Economy & 1.93 \\
Education & 2.98 \\
Social Relationship & 3.08 \\
\hline Average & $\mathbf{2 . 2 5}$ \\
\hline
\end{tabular}


Of the three groups of people, it turns out environmental quality has a value of 1.80 , which is below the number 2, so it makes quadrant LESS WELL. As for the quality of life has a value of 2.25 is entered into quadrants GOOD. Image explanation the position can be seen in figure below:

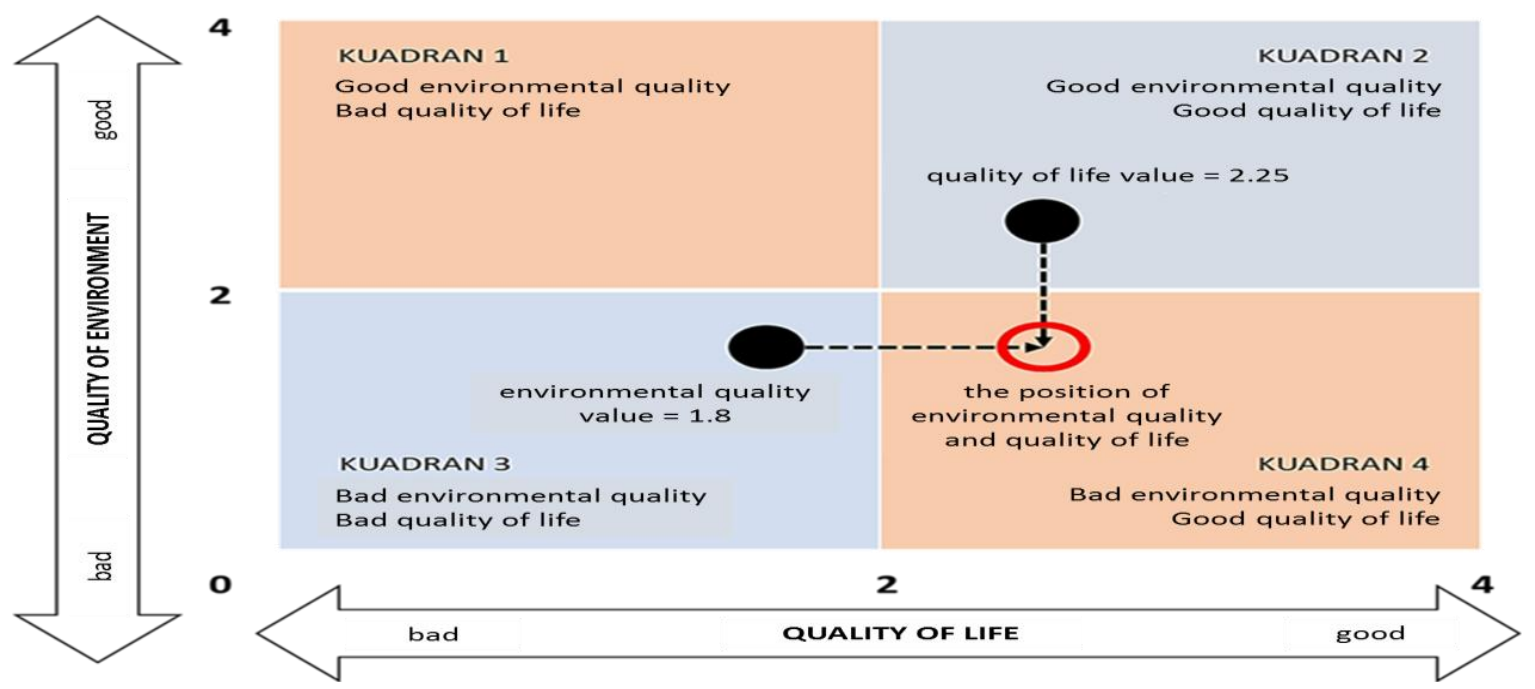

Figure 10: Position value of the quality of life and environmental quality, in quadrant 4, which show that environmental quality is still bad, but the Quality of Life has been good.

\section{CONCLUSION}

It turned out that the environmental conditions in settlements located in Trimulyo is categorized as poor. Nevertheless majority of the people stated that the environment comfortable to be used as a residence.

Their quality of life has been categorized as good, especially to their satisfaction in the field of education and social relationships.

So that it can be concluded that not all the physical environmental conditions that are less good (bad) would have a quAlity of life that is nothing good as well, because anyone who has lived long in an area, would feel more comfortable and at ease living with their neighbors who also have long stay in that place. Kinship can be created through togetherness within a period long enough in life together. With good kinship will create a good community atmosphere, a good community atmosphere will raise the quality of life.

The educational facilities that already exist in the region, starting from elementary to university greatly benefit people in the education of children and families. In addition, due to their neighborhoods adjacent to an industrial area, it demands skills that correlate with the level of education, making local communities have an average education at the level of associate experts. This also raises the quality of life, compared to agricultural areas that do not need educated personnel.

People's satisfaction in doing good social relationships, and the quality of education they have, could be social capital for the physical development of their neighborhoods for the better.

\section{ACKNOWLEDGMENT}

Our thanks to all those who have helped this research, to village officials, the local RT and RW, and the Sub-District of Genuk, as well as friends in Bappeda (planning and regional development agencies) of Semarang. Also thanks to Prof. DR. Sugiono Soetomo, DEA and Prof. Sudharto P Hadi, MES, PhD. who have helped and give feedback that is very meaningful. To Gleb Bezgin, Alfi Afadiyanti, Bagus Al Farazi, and friends, thank you for taking the time to assist the correction of language, field survey activities, and charging tabulation.

\section{BIBLIOGRAPHY}

[1] Bigio A.G. 2003. Cities and climate change. In: Alcira K., Arnold M., and Carlin A. (eds.) Building Safer Cities: The Future of Disaster Risk. Washington, USA: World Bank, page 91-99.

[2] Bintarto, R., 1977, "Geografi Kota, Pengantar", Yogyakarta: Spring.

[3] Bronfenbrenner U. 1979. The ecology of human development: experiments by nature and design. Cambridge, Massachusetts: Harvard University Press. 
[4] Budihardjo, Eko. 1998. Arsitektur dan Kota di Indonesia,Bandung : PT. Alumni, Cetakan ke-4.

[5] Budihardjo, Eko. 1997. Tata Ruang Perkotaan. Bandung : PT. Alumni.

[6] Budihardjo, Eko. 1996. Lingkungan Binaan dan Tata Ruang Kota. Bandung : PT. Alumni.

[7] Canter, David, 1970, Architectural Psychology, London: RIBA

[8] Catanese, Antoni J. 1986. Pengantar Perencanaan Kota, Surabaya : Erlangga

[9] Douglas J. , 2006. Building Adaptation. Edinburg, UK: Routledge.

[10] Halim D. 2005. Psikologi arsitektur. Jakarta, Indonesia: Grasindo.

[11] Harwitasari D., \& van Ast, J.A. 2011. Climate change adaptation in practice: people's responses to tidal flooding in Semarang, Indonesia. Journal of Flood Risk Management, 4, 216-233.

[12] Hutchison R. 2010. Urban Study. New York, USA: SAGE Publication.

[13] Hadi P, Sudharto, 2001, "Dimensi Lingkungan Perencanaan Pembangunan”, Gadjah Mada University Press, Yogyakarta.

[14] Hughes, 1974, Suburbanization Dynamics and the Future of the City, CUPR, Rutgers, New Brunswick

[15] Khadiyanto P. 2005. Tata Ruang Berbasis Pada Kesesuaian Lahan. Semarang, Indonesia: Badan Penerbit Universitas Diponegoro.

[16] Klien D.C. 2005. Psikologi Tata Kota (terjemahan). Yogyakarta, Indonesia: Penerbit Alenia.

[17] Kuswartojo, Tjuk, dkk. 2005. "Perumahan dan Permukiman di Indonesia". Bandung: Penerbit ITB.

[18] Maimunah S., Hendri H., Rosli N.S.M., Rafanoharana S.C., Sari K.R., Higashi O. 2011. Strengthening community to prevent better place using participatory approach (a case of the Semarang city). Journal of International Development and Cooperation, 18, (2), 19-28.

[19] Marsella J. 2004. Arsitektur Dan Perilaku Manusia. Jakarta: Grasindo.

[20] Maslow A.H. 1943. A theory of Human Motivation. Psychological Review, 50, (4), 370-396.

[21] Nawawi H. 1987. Metode penelitian bidang sosial. Yogyakarta, Indonesia: Gadjah Mada University Press.

[22] Parvin A., Alam A.F.M.A. \& Asad R. 2014. Climate change impact and adaptation in urban informal settlements in Khulna: A built environmental perspective. Libre, in press.

[23] Phelan L., Taplin R., Henderson-Sellers A. \& Albrecht G. 2011. Ecological viability or liability? Insurance System responses to climate risk. Environmental Policy and Governance, 21, (2), 112-130.

[24] Planning And Regional Development Agencies Semarang City, 2010, Semarang in Figure 2010.

[25] Samsunuwiyati P. 2006. Perilaku manusia, PT. Bandung, Indonesia: Refika Aditama.

[26] Sarwono, S.W. 1992. Psikologi lingkungan. Jakarta, Indonesia: Rasindo Jakarta.

[27] Soemarwoto, Otto. 1991. Ekologi, Lingkungan Hidup dan Pembangunan. Jakarta: Djambatan.

[28] Statistic Bureau Semarang. 2014. Potensi Kota. Semarang, Indonesia: Statistic Bureau.

[29] Suparlan Y.B. 1991. Kamus Indonesia Kawi. Yogyakarta, Indonesia: Pustaka Pelajar.

[30] Turner, John F.C, 1976. Housing By People : Towards Autonomy in Building Environments. London : Marios Boyars

[31] Turvey R. 2007. Vulnerability assessment of developing countries: the case of small-island developing states. Developing Policy Review, 25, (2), 243-264.

[32] Ward P.J., Marfai M.A., Yulianto F., Hizbaron D.R. \& Aerts J.C.J.H. 2011. Coastal inundation and damage exposure estimation: a case study for Jakarta. Natural Hazards, 56, 899-916. 